\title{
Technology Evaluation for the Big Spring Water Treatment System at the Y-12 National Security Complex, Oak Ridge, Tennessee
}


Tetra Tech, Inc.

contributed to the preparation of this document and should not be considered an eligible contractor for its review. 
BJC/OR-1239

\section{Technology Evaluation for the Big Spring Water Treatment System at the Y-12 National Security Complex, Oak Ridge, Tennessee}

Date Issued—November 2002

Prepared by

Tetra Tech, Inc.

under subcontract 23900-BA-ES008

Prepared for the

U.S. Department of Energy

Office of Environmental Management

\section{BECHTEL JACOBS COMPANY LLC}

managing the

Environmental Management Activities at the

East Tennessee Technology Park

Y-12 National Security Complex Oak Ridge National Laboratory

Paducah Gaseous Diffusion Plant Portsmouth Gaseous Diffusion Plant

under contract DE-AC05-98OR22700 for the

U.S. DEPARTMENT OF ENERGY 



\section{CONTENTS}

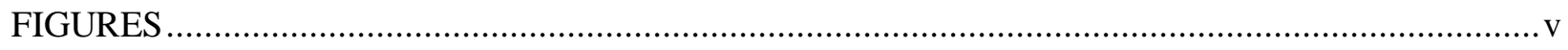

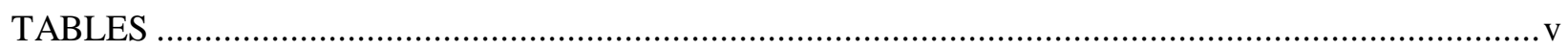

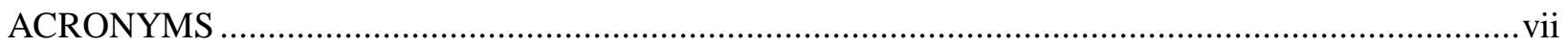

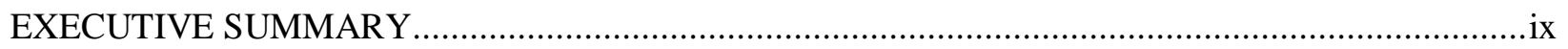

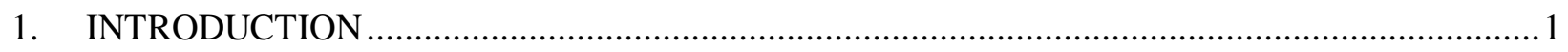

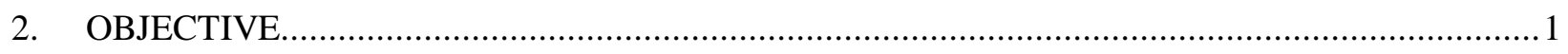

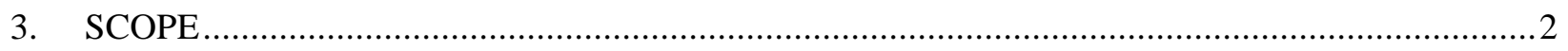

4. DESCRIPTION OF TECHNOLOGIES ….....................................................................

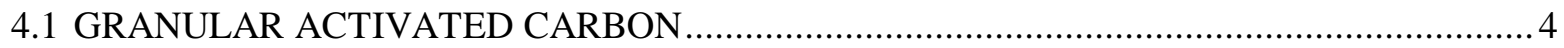

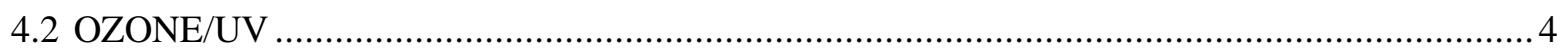

5. MERCURY REMOVAL CAPABILITIES ..................................................................... 7

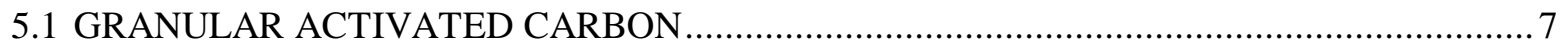

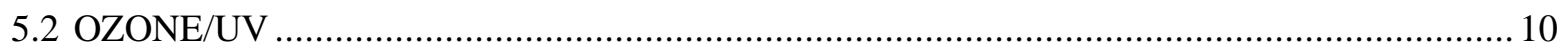

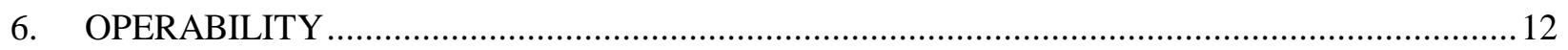

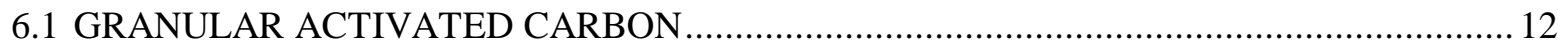

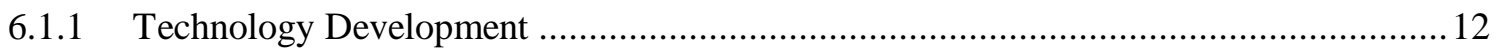

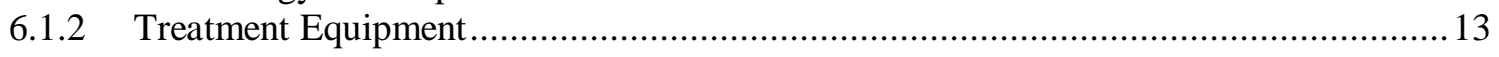

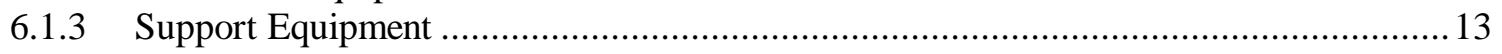

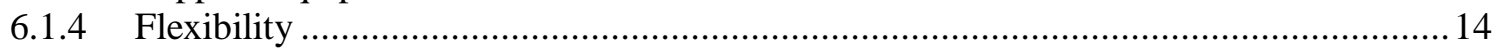

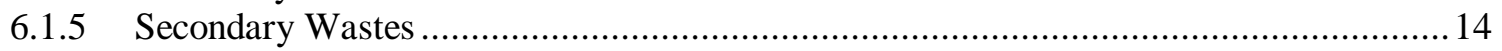

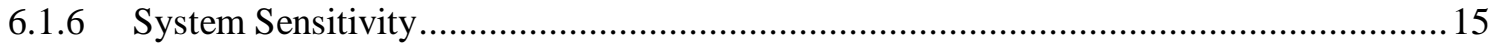

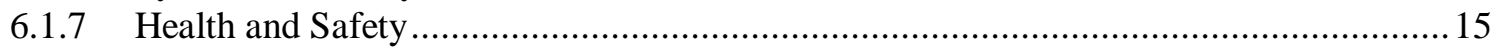

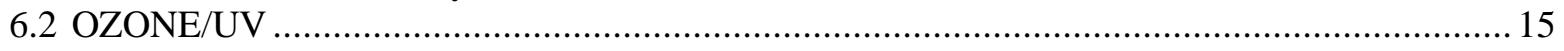

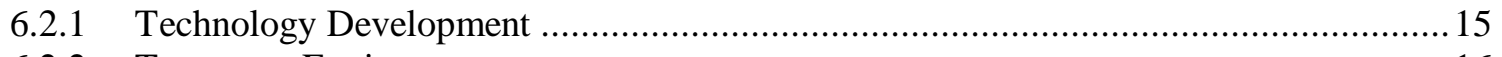

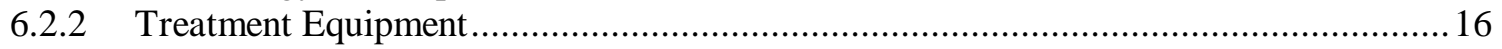

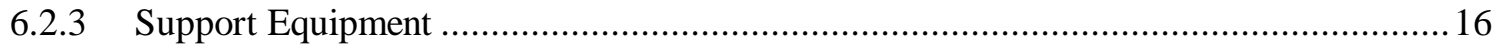

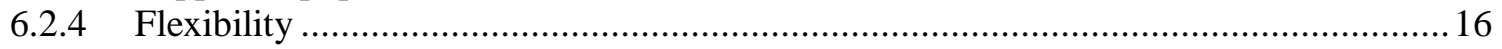

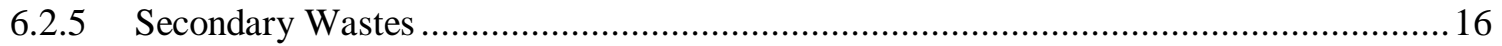

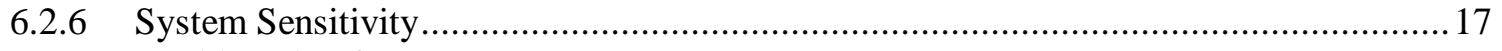

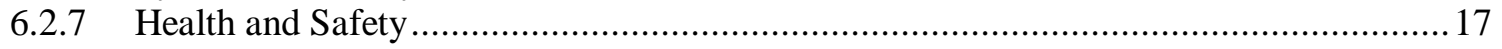

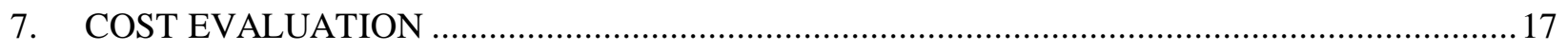

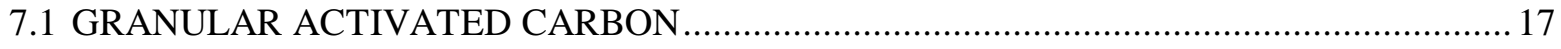

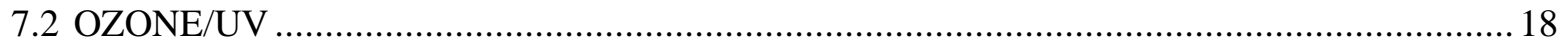

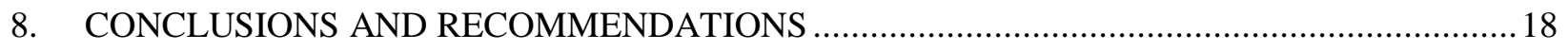

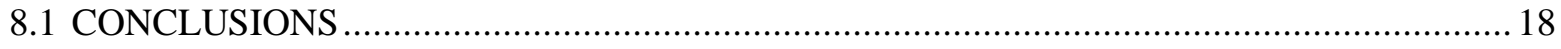

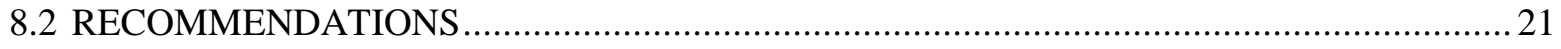





\section{FIGURES}

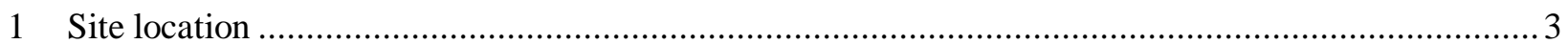

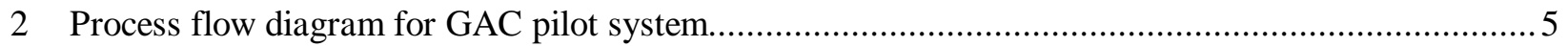

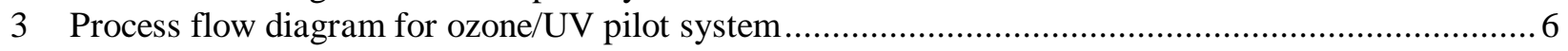

4 Influent and effluent mercury concentrations from GAC pilot system …..................................... 8

5 Effluent mercury concentrations from GAC pilot system compared to treatment limit and goal......... 9

6 Effluent mercury concentrations from ozone/UV pilot system compared to treatment limit and goal 11

7 Average $\mathrm{pH}$ results from GAC pilot system ........................................................................... 14

\section{TABLES}

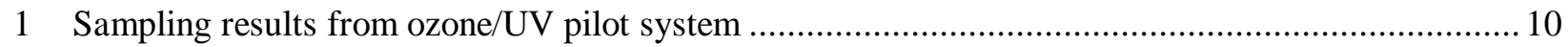

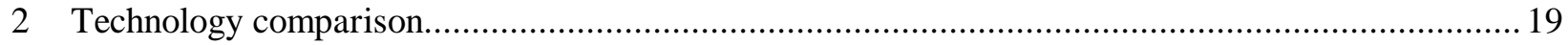





\section{ACRONYMS}

$\begin{array}{ll}\text { AWQC } & \text { Ambient Water Quality Criteria } \\ \text { BJC } & \text { Bechtel Jacobs Company LLC } \\ \text { CMTS } & \text { Central Mercury Treatment System } \\ \text { DOE } & \text { U.S. Department of Energy } \\ \text { EEMTS } & \text { East End Mercury Treatment System } \\ \text { GAC } & \text { granular activated carbon } \\ \text { O\&M } & \text { operation and maintenance } \\ \text { PVC } & \text { polyvinyl chloride } \\ \text { ROD } & \text { Record of Decision } \\ \text { UEFPC } & \text { Upper East Fork Poplar Creek } \\ \text { UV } & \text { ultraviolet } \\ \text { WETF } & \text { West End Treatment Facility } \\ \text { Y-12 Complex } & \text { Y-12 National Security Complex }\end{array}$





\section{EXECUTIVE SUMMARY}

According to the Record of Decision for Phase I Interim Source Control Actions in the Upper East Fork Poplar Creek Characterization Area, Oak Ridge, Tennessee, issued in May 2002, a new $300 \mathrm{gpm}$ water treatment system is to be constructed and operated to remove total mercury from groundwater discharged from Outfall 51 in addition to the groundwater collected in the basement sumps of Bldg. 9201-2. Therefore, to reduce the amount of mercury being released to Upper East Fork Poplar Creek, the Big Spring Water Treatment System will be designed and constructed as a Comprehensive Environmental Response, Compensation, and Liability Act action. This facility is to be designed to treat the combined flow from the large natural spring discharging to Outfall 51 and the inflow now being processed at the East End Mercury Treatment System.

A pre-design study was performed to investigate the applicability of various treatment technologies for reducing mercury discharges at Outfall 51 in support of the design of the Big Spring Water Treatment System. This document evaluates the results of the pre-design study for selection of the mercury removal technology for the treatment system. The approach to the predesign studies was to operate/evaluate a traditional baseline technology compared to another innovative technology to achieve the concentration of total mercury in water to below $51 \mathrm{ng} / \mathrm{L}$. The baseline technology consisted of filtration and granular activated carbon (GAC) adsorption. The innovative technology was filtration, oxidation/reduction using ozone/ultraviolet (UV) light, followed by air stripping. This treatment technology was selected based on bench-scale, laboratory studies performed by UT-Battelle. Results from the field ozone/UV system are compared with the baseline to determine the effectiveness and implementabilty of the system.

Activated carbon is a conventional treatment technology that has a proven track record of treatment efficiency, operability, and reliability. During the Phase II study, discharge levels were below the $200 \mathrm{ng} / \mathrm{L}$ discharge limit established in the Record of Decision (ROD). The effluent data also imply that there is a potential for achieving the $51 \mathrm{ng} / \mathrm{L}$ discharge goal through the installation of three columns each with an 8 -ft bed depth operated in series.

The field ozone/UV system also demonstrated the ability to obtain mercury discharge levels below $200 \mathrm{ng} / \mathrm{L}$, although effluent mercury concentrations from the activated carbon system were generally lower. As such the ozone/UV technology has considerable potential for mercury removal without generating significant quantities of secondary waste. The primary disadvantage of the ozone/UV system is the lack of technical maturity for treating mercury.

Based on the information evaluated in this report, it is recommended that the full-scale water treatment system be designed and constructed using GAC as the mercury removal technology. In an attempt to obtain mercury discharge levels below $51 \mathrm{ng} / \mathrm{L}$, it is recommended that an extra column be added to the two-column configuration used in the pilot study. The treatment system would consist of two parallel $150 \mathrm{gpm}$ trains of three columns in series for a maximum 300 -gpm flow rate as required in the ROD. The levels of mercury removal reported using the ozone/UV studies indicate this technology has a promising future, if developed further. 


\section{INTRODUCTION}

The Y-12 National Security Complex (Y-12 Complex) is an active manufacturing and developmental engineering facility that is located on the U.S. Department of Energy (DOE) Oak Ridge Reservation. Building 9201-2 was one of the first process buildings constructed at the Y-12 Complex. Construction involved relocating and straightening of the Upper East Fork Poplar Creek (UEFPC) channel, adding large quantities of fill material to level areas along the creek, and pumping of concrete into sinkholes and solution cavities present within the limestone bedrock. Flow from a large natural spring designated as "Big Spring" on the original 1943 Stone \& Webster Building 9201-2 Field Sketch FS6003 was captured and directed to UEFPC through a drainpipe designated Outfall 51. The building was used from 1953 to 1955 for pilot plant operations for an industrial process that involved the use of large quantities of elemental mercury.

Past operations at the Y-12 Complex led to the release of mercury to the environment. Significant environmental media at the site were contaminated by accidental releases of mercury from the building process facilities piping and sumps associated with Y-12 Complex mercury handling facilities. Releases to the soil surrounding the buildings have resulted in significant levels of mercury in these areas of contamination, which is ultimately transported to UEFPC, its streambed, and off-site. Bechtel Jacobs Company LLC (BJC) is the DOE-Oak Ridge Operations prime contractor responsible for conducting environmental restoration activities at the Y-12 Complex.

In order to mitigate the mercury being released to UEFPC, the Big Spring Water Treatment System will be designed and constructed as a Comprehensive Environmental Response, Compensation, and Liability Act action. This facility will treat the combined flow from Big Spring feeding Outfall 51 and the inflow now being processed at the East End Mercury Treatment System (EEMTS). Both discharge to UEFPC adjacent to Bldg. 9201-2. The EEMTS treats mercury-contaminated groundwater that collects in sumps in the basement of Bldg. 9201-2.

A pre-design study was performed to investigate the applicability of various treatment technologies for reducing mercury discharges at Outfall 51 in support of the design of the Big Spring Water Treatment System. This document evaluates the results of the pre-design study for selection of the mercury removal technology for the treatment system.

\section{OBJECTIVE}

The Record of Decision for Phase I Interim Source Control Actions in the Upper East Fork Poplar Creek Characterization Area, Oak Ridge, Tennessee (DOE 2002), was issued in May 2002. One of the principal actions included in the Record of Decision (ROD) is as follows:

A new 300-gal/min water treatment system will be constructed to remove mercury from groundwater discharge from Outfall 51 and groundwater collected in dewatering sumps in Bldg. 9201-2. The new treatment system will replace an existing system that currently treats contaminated dewatering sump effluents. Outfall 51 is a mercurycontaminated spring that discharges to Upper East Fork Poplar Creek (UEFPC). The water treatment system will be designed using best available technology and is anticipated to reduce mercury to $200 \mathrm{ppt}$ at a minimum in the system effluent. 
Additional methods for removal of mercury, potentially bringing levels to the ambient water quality criteria (AWQC) of $51 \mathrm{ppt}$, will be evaluated as part of a pre-design characterization and testing study. It is expected that the 200-ppt interim mercury goal will be achieved after construction and startup of the treatment system.

This document presents the results of the mercury removal efficiency for field studies of two treatment technologies on groundwater currently discharging through Outfall 51. Recommendations are presented on the technology for deployment in the $300 \mathrm{gpm}$ treatment system.

\section{SCOPE}

Mercury at a concentration of approximately 1400 to $5000 \mathrm{ng} / \mathrm{L}$ (or ppt) exists in different forms in the discharge at Outfall 51. Limited data from mass balances performed during the pilot studies at Outfall 51 indicate that approximately $28 \%$ of the mercury is present as elemental mercury [ $\mathrm{Hg}(0)], 33 \%$ is present as dissolved $\mathrm{Hg}$ (II) and $39 \%$ is of a refractory form $\mathrm{Hg}$ (I). The term refractory is being used to designate the fraction of mercury that cannot be converted to elemental mercury in the presence of stannous [Sn (II)] chloride, which is added to samples before analysis. During previous air stripping tests, several system configurations were tested and, on average, 16-23\% of the mercury was found to be of a refractory form. Addressing the refractory fraction of mercury is important in meeting the goal of bringing discharge levels to 200 $\mathrm{ng} / \mathrm{L}$ or less as well as in the evaluation of the ability to achieve the AWQC of $51 \mathrm{ng} / \mathrm{L}$.

The approach to the pre-design studies was to operate/evaluate a traditional baseline technology compared to other innovative technologies to achieve the concentration of total mercury in water to below $51 \mathrm{ng} / \mathrm{L}$. The baseline technology selected was filtration and GAC adsorption. The innovative technology was filtration, oxidation/reduction using ozone and ultraviolet (UV) light, followed by air stripping. This treatment technology was selected based on bench-scale, laboratory studies performed by UT-Battelle researchers. Results from the field ozone/UV system were compared with the baseline to determine the effectiveness and implementabilty of the system.

The pre-design studies were conducted at the Y-12 Complex near Outfall 51, which is located adjacent to Bldg. 9201-2 as shown in Fig. 1. Outfall 51 provides a discharge outlet to Big Spring, which is found underneath an asphalt parking area located between the actual UEFPC discharge point and Bldg. 9201-2. A concrete box located $8-10$ feet below the pavement serves as a collection structure for the spring. From the box, the spring water flows by gravity through an underground pipe to the creek. The hydrogeologic features of the spring are not well known. However, the water elevation at the creek can rise to levels that would be equal to or higher than the elevations of the spring box and the piping system leading to UEFPC, thus creating the potential for backflow into the box. The pilot units for the pre-design studies collected mercurycontaminated water from an existing well $(\mathrm{GW}-833)$ installed in the top of the spring box above Big Spring. 


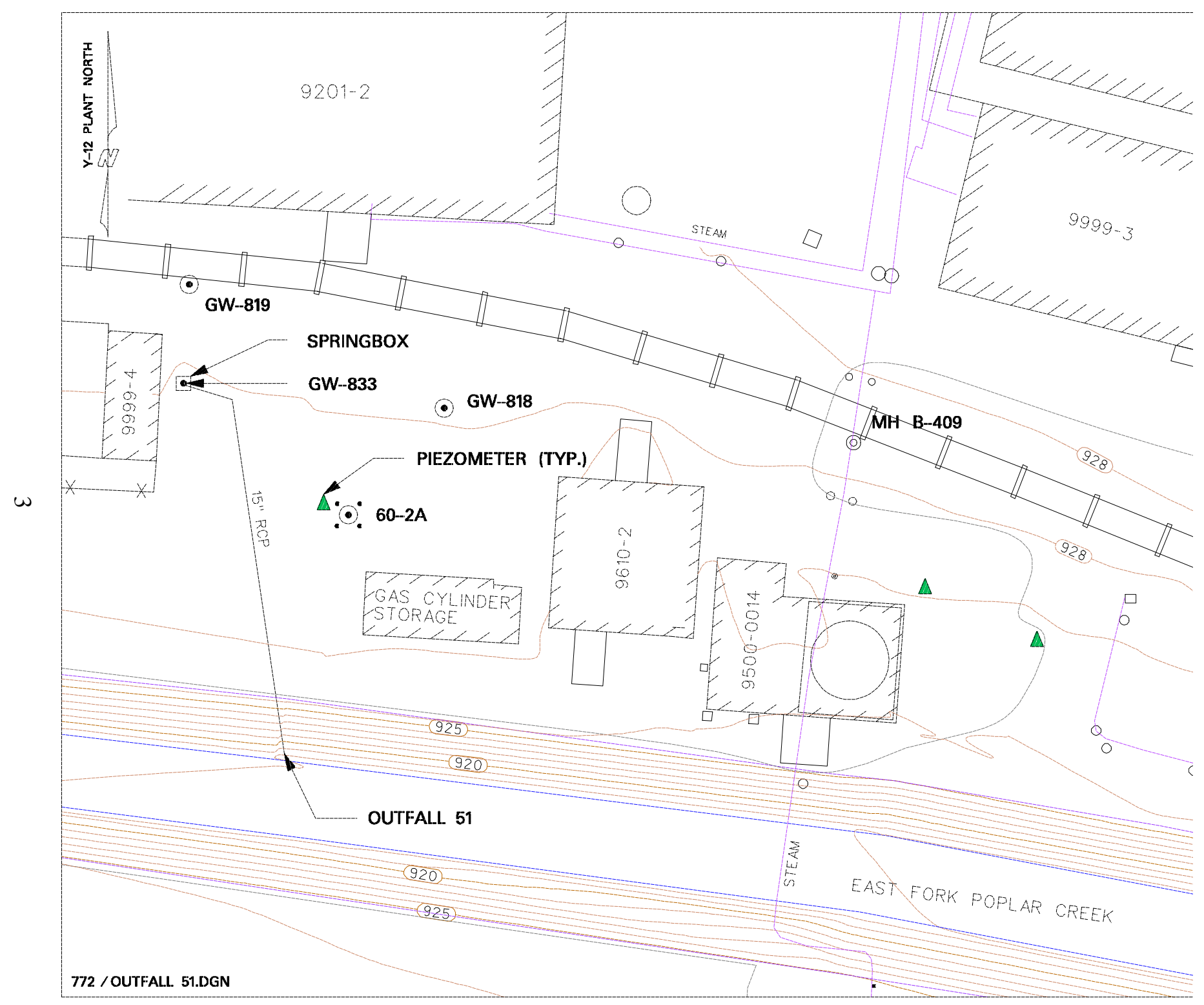

Fig. 1. Site location. 


\section{DESCRIPTION OF TECHNOLOGIES}

\subsection{GRANULAR ACTIVATED CARBON}

The pilot activated carbon unit consisted of four GAC columns, each 4-in. diameter and $5 \mathrm{ft}$ high, operated in series at a bed velocity of $2.98 \mathrm{gpm} / \mathrm{ft}^{2}$. The columns were set up with vents to allow removal of any gases that build up as a result of spring water outgasing. A flow diagram of the pilot-scale GAC adsorption system is shown in Fig. 2. The system included two sets of filters. The first set was positioned before the first column to remove solids down to approximately 5 micron. The second filter was placed after the fourth column to remove carbon fines from the discharge during sampling events. Based on recommendations from Calgon Carbon Corporation technical support, each column was filled to a packed depth of $4 \mathrm{ft}$ with Filtrasorb ${ }^{\mathrm{TM}} 600$, which is a 12 x 40-mesh activated carbon. This configuration was selected to model the operation of two carbon columns in series, each containing an 8-ft bed depth allowing for sample collection in the middle of each bed. Filtrasorb ${ }^{\circledR} 600$ carbon was recommended because it provides better trace element removal. After the columns were charged with carbon, the tubing was configured to backwash the system to fluidize the bed and remove fines from the system. The system was operated in the downflow mode for optimal efficiency and to simulate the operating mode of fullscale columns.

\subsection{OZONE/UV}

Laboratory investigations of innovative technologies focused on oxidation/reduction processes to change the chemical form of the mercury in the spring water to enhance its removal efficiency. Strong oxidizers were added to samples of the spring water to chemically react with the elemental and refractory mercury to change it to the dissolved, $\mathrm{Hg}$ (II) form. Once the mercury in the water was fully oxidized, a reducing agent was added to the water to bring it back to the elemental form. Once all of the mercury is reduced to the elemental form, it could be removed easily from the water using conventional air stripping. Oxidation chemicals that were evaluated included hydrogen peroxide, chlorine, potassium permanganate, and ozone. The results of the laboratory studies indicate that ozone had the greatest potential to adequately oxidize the mercury in the spring water. In addition, ozone has the advantage of being readily destroyed using UV light and a minimal amount of reducing agent was required to be added to the water.

Additional batch testing of the ozone/UV system indicated a 5-minute contact time was adequate to dissolve sufficient amounts of ozone to oxidize the mercury. It was also determined that 30 seconds of exposure to UV light would be required to activate the ozone through the generation of hydroxyl $\left(\mathrm{OH}^{\circ}\right)$ radicals, complete the oxidation reaction, and eliminate residual ozone from the water. The laboratory studies also indicated that the chemical reduction of mercury with stannous chloride was nearly instantaneous. As a result, the stannous chloride could be injected into the spring water downstream of the UV reactor and just prior to the air stripper. A flow diagram of the field scale ozone/UV system is shown in Fig. 3.

\footnotetext{
${ }^{\mathrm{TM}}$ Reference herein to any specific commercial product, process, or service by trade name, trademark, manufacturer, or otherwise, does not necessarily constitute or imply its endorsement, recommendation, or favoring by the United States Government or any agency thereof or its contractors or subcontractors.
} 


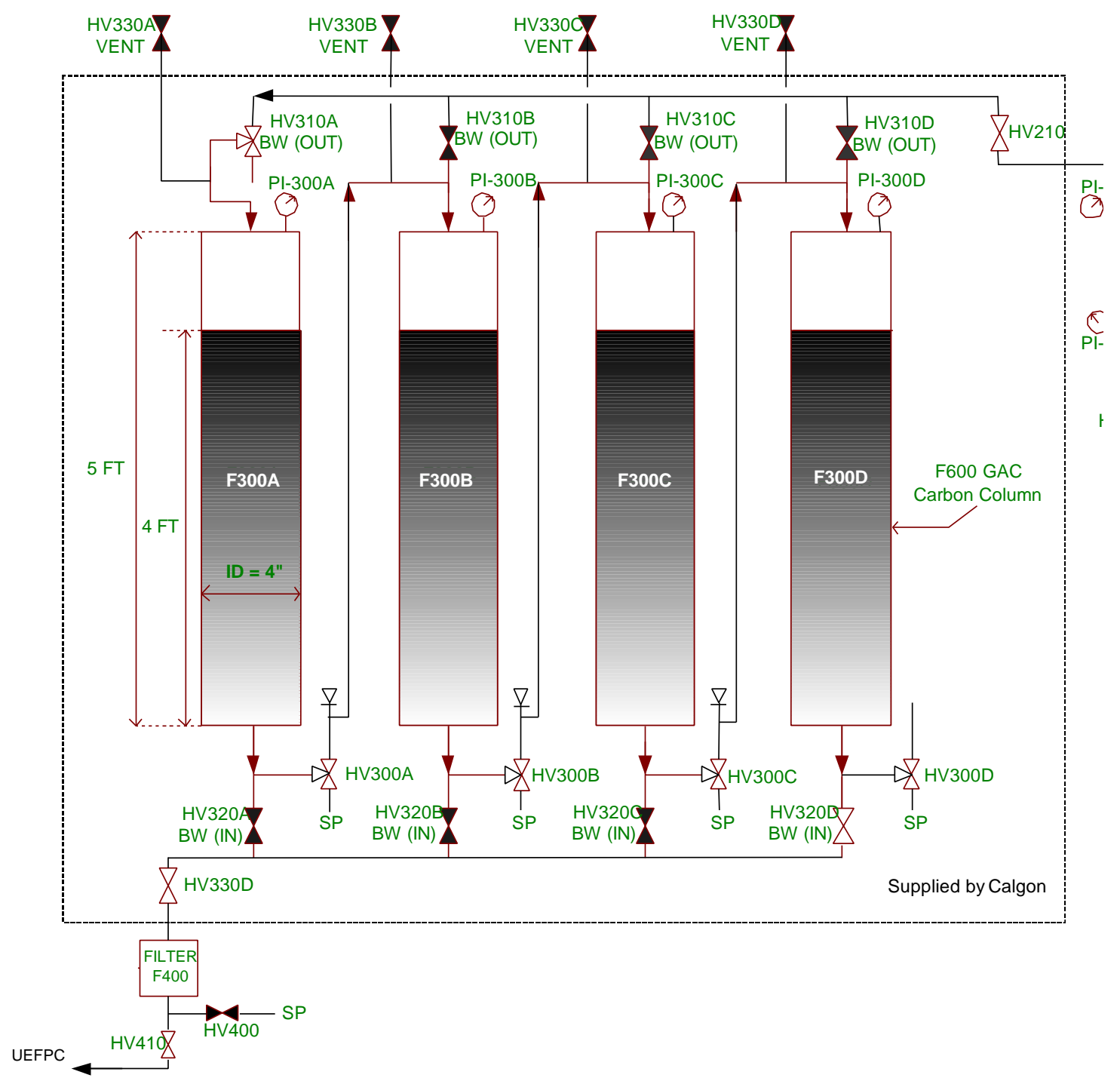

Fig. 2. Process flow diagram for GAC pilot system. 


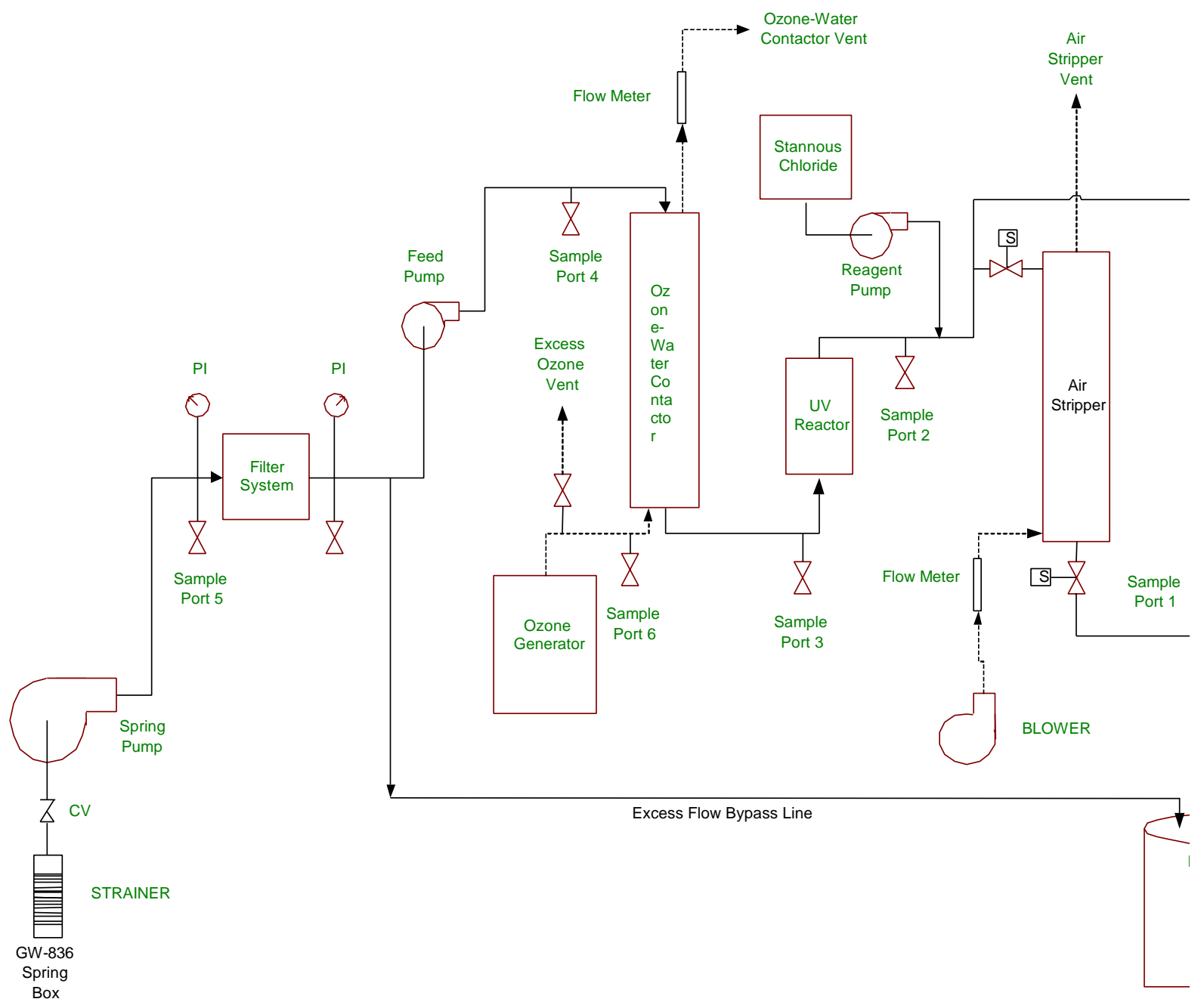

Fig. 3. Process flow diagram for ozone/UV pilot system. 


\section{MERCURY REMOVAL CAPABILITIES}

The mercury removal capability for the pilot systems of each technology is presented below. Observations and changes in the field conditions are also described. In general, the mercury removal capabilities of both technologies could consistently meet the $200 \mathrm{ng} / \mathrm{L}$ discharge limit documented in the ROD. In addition, discharge levels below $100 \mathrm{ng} / \mathrm{L}$ also appear to be attainable for either technology. The activated carbon system appears to have an initial spike that exceeds $100 \mathrm{ng} / \mathrm{L}$ during the period when residual fines may still be flushed from the system.

\subsection{GRANULAR ACTIVATED CARBON}

Figures 4 and 5 show the results for the Phase II pilot scale runs using GAC. The Phase I carbon system was run for approximately 24 days of operation when a significant amount of algae was observed in the tubing and the carbon columns. The presence of algae in the columns was postulated to have a negative effect on the mercury removal effectiveness of the carbon. The algae growth in the columns was attributed to continuous illumination from sunlight, streetlights, and a large mercury vapor lamp in the vicinity of the system. As a result, the system was shut down, manually scrubbed, reassembled with new tubing, and recharged with fresh carbon. The columns were draped with black plastic sheet and the tubing covered with foam insulation material to eliminate light energy from reaching the system. Once the system was backwashed, it was placed on line for Phase II testing. No further algae growth was noted after elimination of radiant energy from the pilot plant system.

The maximum mercury effluent concentration of $134 \mathrm{ng} / \mathrm{L}$ was reached during the first 14 days of operation of the Phase II system (see Fig. 5). This initial spike was attributed to the presence of carbon fines in the columns that were not completely flushed during the initial backwash. After the initial peak, the columns attained an equilibrium discharge concentration near the 51-ng/L goal; the minimum measured value was $26 \mathrm{ng} / \mathrm{L}$ on day 31 . A second, smaller peak of approximately $80 \mathrm{ng} / \mathrm{L}$ was measured on day 42, which corresponded to the change out of the two pre-filters for the system.

As shown in Fig. 4, the filtered influent mercury concentration often exceeded the unfiltered influent concentration. This phenomenon could not be explained although several system and sample modifications were tested. In addition, this phenomenon was observed during previous testing of column systems with pre-filtration at the Y-12 Complex North-South Pipes. Data from the tests indicated mercury concentrations in the effluent from the filter exceeded the unfiltered in all but one sample. It is postulated that this phenomenon is the result of a change in chemical species of the mercury trapped on the filter that allows mercury to leach into the water. The pilot scale system demonstrated that it was not impacted by the variability of influent concentration or pre-filtration. Because pre-filtration of the influent was included in the system to protect the carbon columns from fouling due to silts and sediments and not for mercury removal, the increase in mercury concentration after filtration was not evaluated further. 


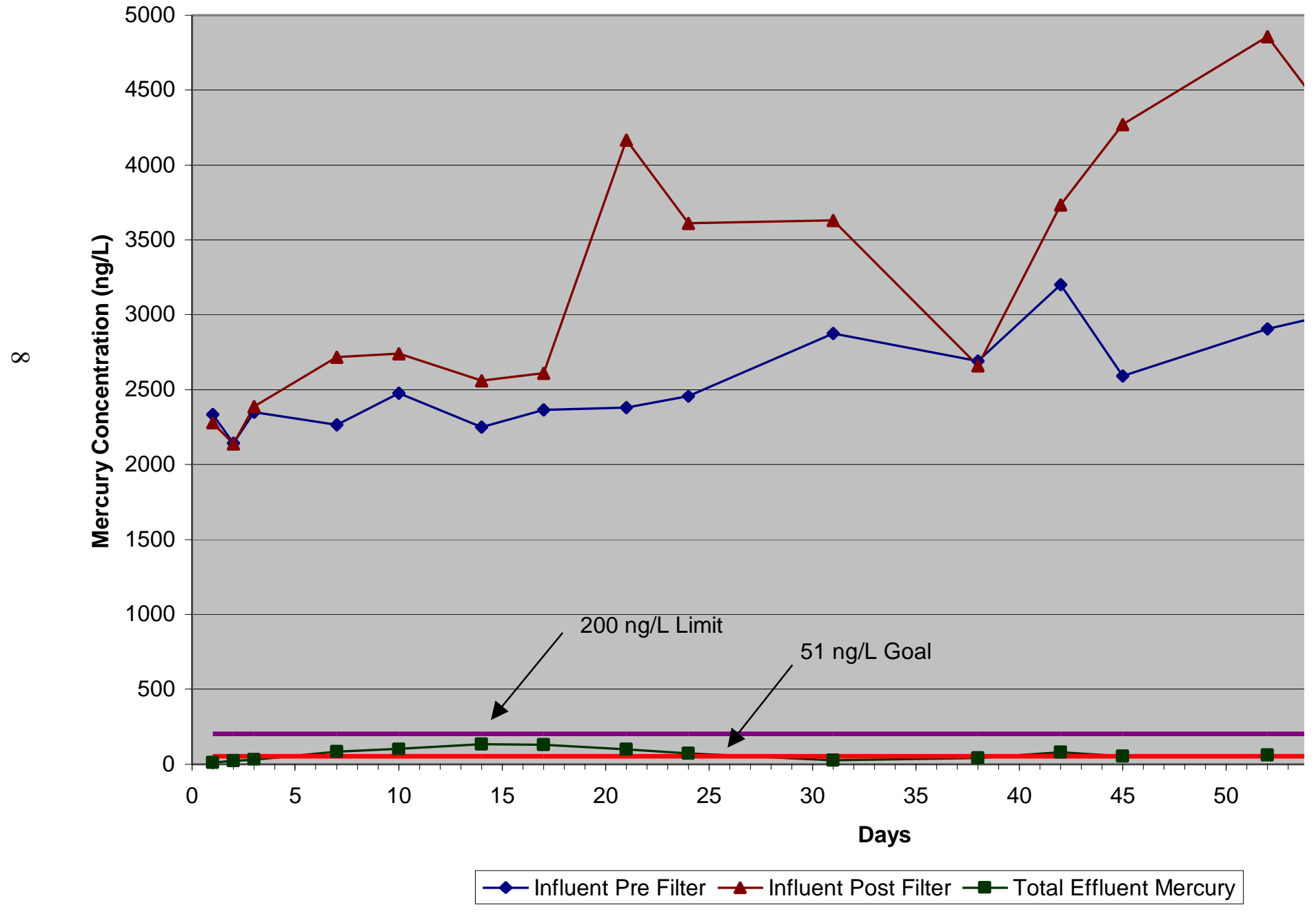

Fig. 4. Influent and effluent mercury concentrations from GAC pilot system. 


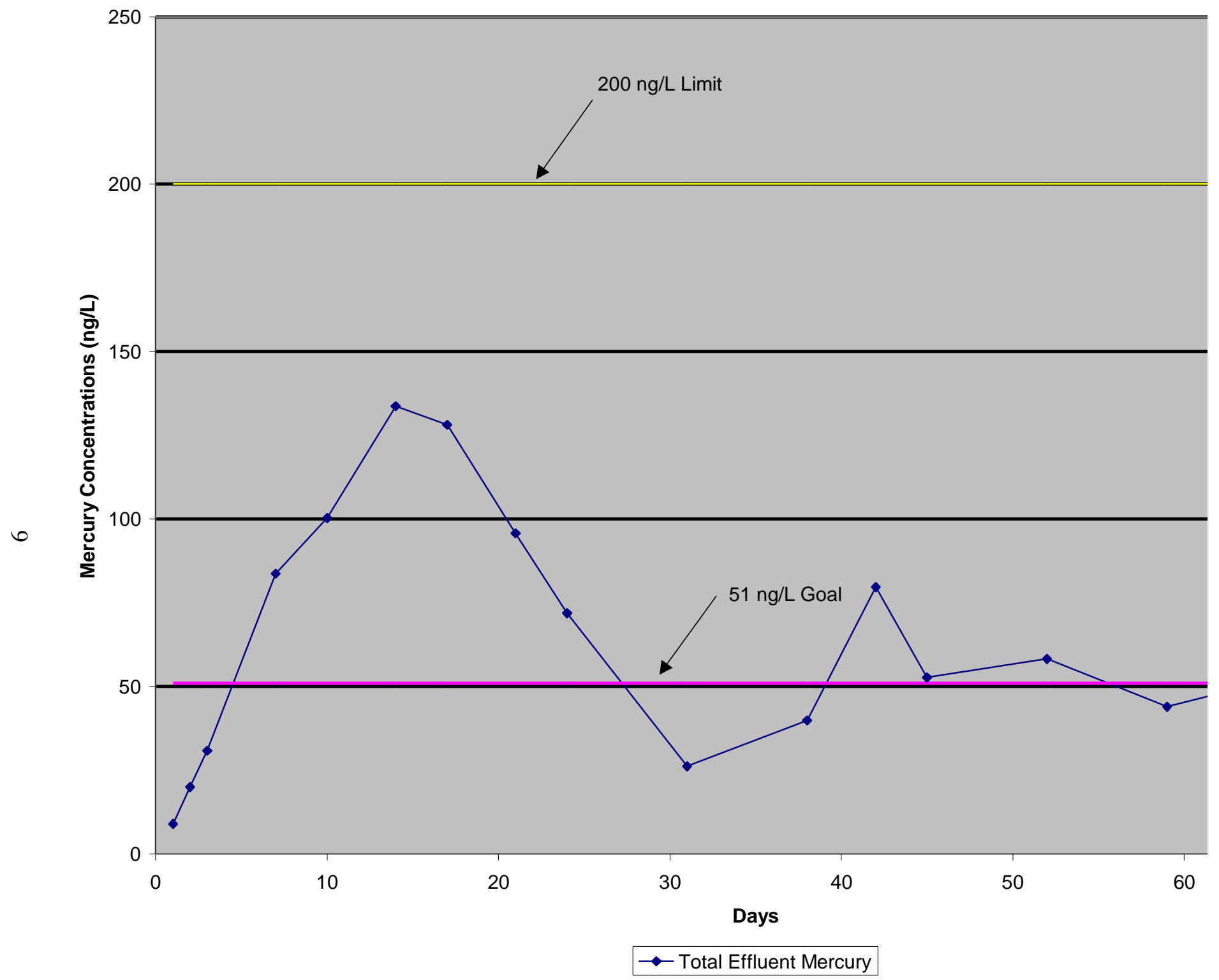

Fig. 5. Effluent mercury concentrations from GAC pilot system compared to treatment limit and ; 
The system was operated continuously for approximately 60 days during which time it never exceeded the 200-ng/L discharge limit. Based on the data, it does not appear the columns approached exhaustion/breakthrough for the 200-ng/L limit. As a result, a treatment system consisting of two carbon columns each with an 8-ft bed depth, operated in series would be adequate to consistently meet the discharge limits documented in the ROD. The columns would be 8 -ft diameter to accept a flow rate of $150 \mathrm{gpm}$. To meet the 300 -gpm design requirement, two parallel trains would be required. The data also imply that there is a potential for achieving the 51-ng/L discharge goal through the installation of three columns each with an $8 \mathrm{ft}$ bed depth operated in series.

\subsection{OZONE/UV}

The results of the ozone/UV study are presented in Table 1 and Fig. 6. The pilot ozone/UV system was set up and operated by UT-Battelle personnel. The system consisted of a filter, ozone generator, ozone-water contactor, UV reactor, stannous chloride addition system, and air stripper. A flow diagram of the pilot-scale system is shown in Fig. 3. The system also included a spring pump to pull water from the spring box at a rate of approximately $1000 \mathrm{ml} / \mathrm{min}$ followed by a filter to remove particulate matter. The spring pump was followed by the treatment system feed pump that initially operated at approximately $200 \mathrm{~mL} / \mathrm{min}$. Excess water pulled up by the spring pump was diverted to the product drum prior to discharge.

Table 1. Sampling results from ozone/UV pilot system

\begin{tabular}{ccccc}
\hline & \multicolumn{4}{c}{ Mercury concentration (ng/L) } \\
\cline { 2 - 5 } $\begin{array}{c}\text { Sample } \\
\text { Event }\end{array}$ & $\begin{array}{c}\text { Influent } \\
\text { (unfiltered) }\end{array}$ & $\begin{array}{c}\text { Influent } \\
\text { (filtered) }\end{array}$ & $\begin{array}{c}\mathbf{O}_{3} \\
\text { Reactor }\end{array}$ & Effluent \\
\hline 1 & 1938 & 1570 & 1727 & 67 \\
2 & 1982 & 1688 & 1693 & 81 \\
3 & 2041 & 1131 & 1423 & 82 \\
4 & 2195 & 1723 & 1761 & 102 \\
5 & 2658 & 1855 & 1917 & 148 \\
\hline
\end{tabular}

The feed pump supplied water to the ozone-water contactor, a water-jacketed 1.5-in.diameter, 41-in.-tall clear polyvinyl chloride (PVC) pipe that provided a 5-minute liquid phase residence time. The water jacket maintained a $19^{\circ} \mathrm{C}$ temperature in the ozone-water reactor. Ozone was bubbled through the water in the contactor using a Model L-100 Ozonology generator. Excess ozone produced by the generator was vented to the atmosphere. Table 1 shows no mercury removal in the ozone reactor. The elemental mercury is rapidly oxidized and not allowed to volatilize to the gas phase. The oxidized mercury/ozone water solution gravity flowed into an Aquafine Model SP-1 ${ }^{\mathrm{TM}}$ UV reactor with a 30 -second residence time where the $\mathrm{OH}^{\bullet}$ radical is generated, $\mathrm{Hg}$ (I) is oxidized to $\mathrm{Hg}$ (II), and the excess dissolved ozone is destroyed. 


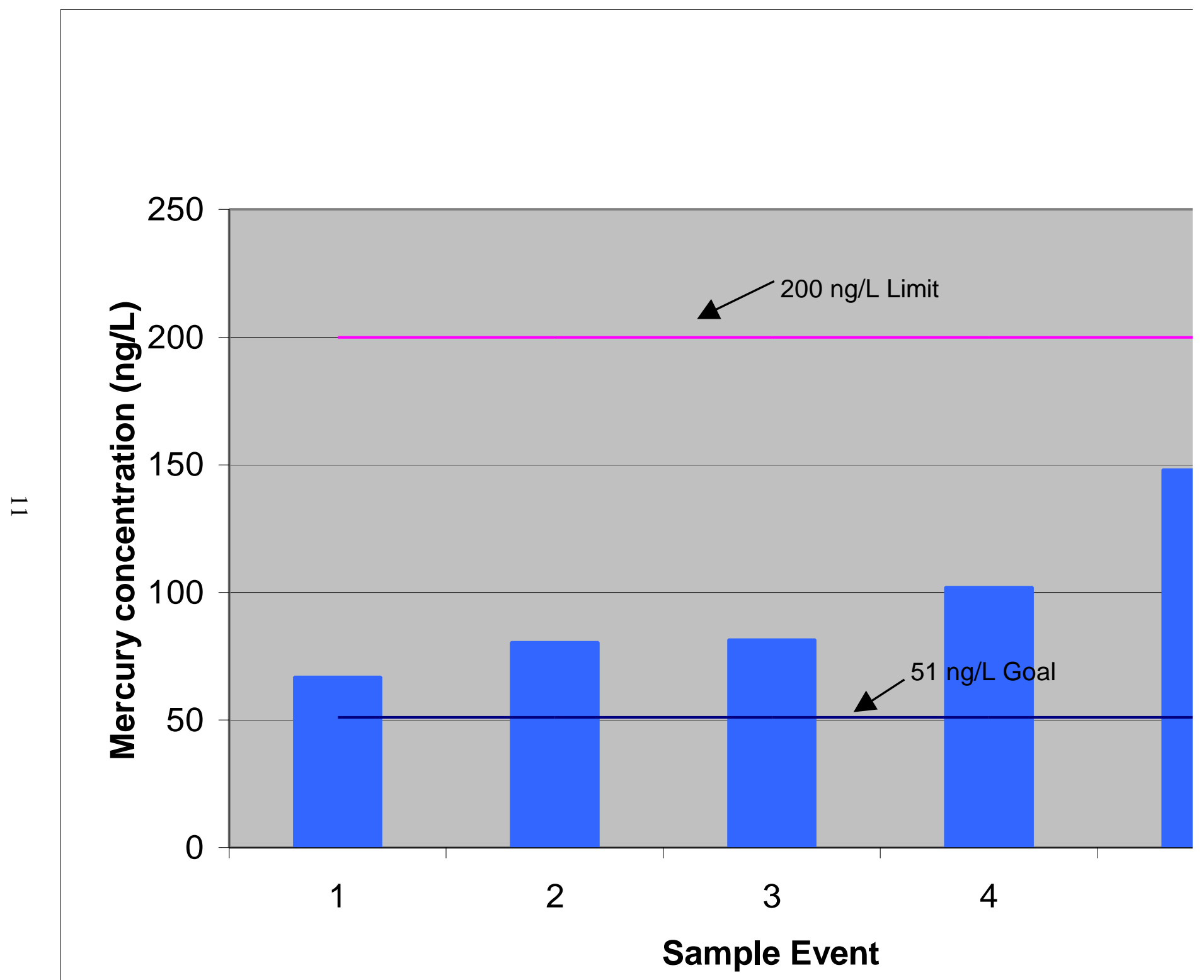

Fig. 6. Effluent mercury concentrations from ozone/UV pilot system compared to treatment limit an 
During the initial operating configuration, water discharged from the UV reactor was mixed with hydroxylamine hydrochloride to eliminate excess dissolved oxidizing agents. This was followed by adding $320 \mathrm{ug} / \mathrm{L}$ stannous chloride $(200 \mathrm{ug} / \mathrm{L} \mathrm{Sn})$ to reduce the mercury from the $\mathrm{Hg}$ (II) to the $\mathrm{Hg}(0)$ form. The water containing reduced mercury gravity flowed to the 2-in.diameter, 34.5-in.-tall clear PVC air stripper. The air stripper operated at a gas-to-liquid flow ratio of 40 to 70 to remove the mercury from the water. The treated water flowed to the product drum to be periodically pumped to the creek. Sampling ports were installed in key locations through out the system for optimization and monitoring treatment effectiveness. Samples collected and analyzed under the initial operating configuration are presented in Table 1 for sample events 1 and 2 .

During setup and operation of the field system, modifications from the original laboratory scale unit were required. Hydroxylamine addition was initially included when the system was deployed in the field. Early field analysis determined that additional reducing agent was required downstream of the UV reactor to maximize the formation of elemental mercury in the water prior to entering the air stripper. The source of the additional reducing agent requirement was not determined. It was later recognized that hydroxylamine would not be an acceptable reducing agent in the full-scale system due to the presence of the ammonium ion. As a result, additional modifications were made to the system including reducing the ozone concentration in the gas from $3 \%$ to $1.3-1.4 \%$ and increasing the stannous chloride feed rate to obtain $300 \mathrm{ug} / \mathrm{L} \mathrm{Sn}$ in the water entering the stripper. Additionally, the initial semi-batch operated air stripper was replaced with a continuous flow stripper. The new stripper consisted of nine trays each approximately 6 in. diameter containing 19 holes, $2.8-\mathrm{mm}$ diameter spaced approximately $21.2 \mathrm{~mm}$ apart. A down flow pipe was provided on each tray to maintain a 0.5-in. liquid depth. Samples collected and analyzed under this operating configuration are presented in Table 1 for sampling events 3, 4, and 5 .

\section{OPERABILITY}

Operability issues for each technology were developed based on discussions with BJC Waste Treatment Operations personnel, commercial product vendors, and analysis of factors effecting the performance of the pilot scale systems. Operational conditions that would affect the performance and/or ergonomics of each technology as it affects a full-scale treatment system are discussed below.

\subsection{GRANULAR ACTIVATED CARBON}

\subsubsection{Technology Development}

GAC is a standard wastewater treatment technology that is familiar to BJC waste operations personnel. The Central Mercury Treatment System (CMTS) and the EEMTS both utilize smaller scale carbon columns to remove mercury from wastewater. In addition the West End Treatment Facility (WETF) utilizes activated carbon as part of its final polishing prior to discharge. This history makes activated carbon an attractive alternative for waste operations personnel due to the experience obtained during CMTS, EEMTS, and WETF operation. 
GAC is efficient and relatively simple to operate. Typically, effluent concentrations do not vary widely as the adsorption zone moves downward through the columns. When a predetermined concentration between columns is measured (i.e., the adsorption zone breaks through the column), the column can be taken off line and the carbon changed out. At that time, the second column becomes the lead column in order to ensure the maximum carbon utilization rate.

\subsubsection{Treatment Equipment}

GAC columns are readily available in standard designs that match the 150 -gpm/train flow rate of the full scale treatment system. No additional information will be required to specify and purchase the equipment. The pre- and post-filters necessary for the design can be purchased offthe-shelf and will be able to take a wide range of cartridges to suite operational requirements.

\subsubsection{Support Equipment}

Operation of the pilot system has demonstrated a need for pre- and post-treatment requirements for the spring water. The initial large perturbation observed in Figs. 4 and 5 may be the result of residual carbon fines being flushed from the columns after the initial backwash. These fines appear to sorb mercury and carry it through the system resulting in higher than normal levels in the discharge. The 5-micron filter used in the discharge of the pilot study collected some of the fines, but it does not appear to have been effective in capturing enough of the smallest particles. It is presumed that lower mercury discharge levels can be obtained during the initial start-up of a column by using a filter with a smaller pore space. A 1-micron filter on the discharge should reduce the magnitude of the perturbation. The installation of a finer filter will result in an increased rate of plugging, which will require additional operator attention on the system. Operational experience at CMTS has indicated that filters as low as 1 micron do not remove all of the fines; therefore, the perturbation is not expected to be completely eliminated.

When the pilot carbon column system was shut down and disassembled, a significant amount of silt was observed in columns one and two. Column three contained significantly less and column four contained almost no observable silt. This observation indicates that the pre-filter system was not adequate to remove sediment from the feed. The pilot system included 15and 5-micron filters to remove silt. It appears that the 5-micron filter was not adequate for this application. In the full-scale system, the wet well and equalization tank will allow large particulates to settle out and not get to the filters. As a result, a 5- and 1-micron filter should be used at the feed to the carbon column to prevent silt from entering the system. Should the 1-micron pre-filter not eliminate the silt buildup in the columns, regularly scheduled backwashing may need to be implemented to maintain the carbon adsorptive capacity.

Data presented in Fig. 7 show the $\mathrm{pH}$ of the water at each sample port over time. This figure indicates that the $\mathrm{pH}$ drops an average of approximately 1 unit across the system. Data from sample ports HV300A, B, C, and D at the discharge of each column indicate that the maximum drop observed across two pilot columns was 0.55 units. Assuming this maximum drop across an additional 8-ft column (two 4-ft pilot columns), a full-scale, three-column system may have a discharge $\mathrm{pH}$ in the range of 5.2. This $\mathrm{pH}$ is below anticipated discharge limits and demonstrates the need for final adjustment. Samples of carbon system discharge water were collected for titration testing to determine the amount of caustic required for maintaining the $\mathrm{pH}$ at acceptable discharge levels. Results of this test indicate approximately $0.13 \mathrm{lb} / \mathrm{hr}$ of sodium hydroxide would be required to raise the $\mathrm{pH}$ from 5.2 to 6.8 in a 150 -gpm train. 


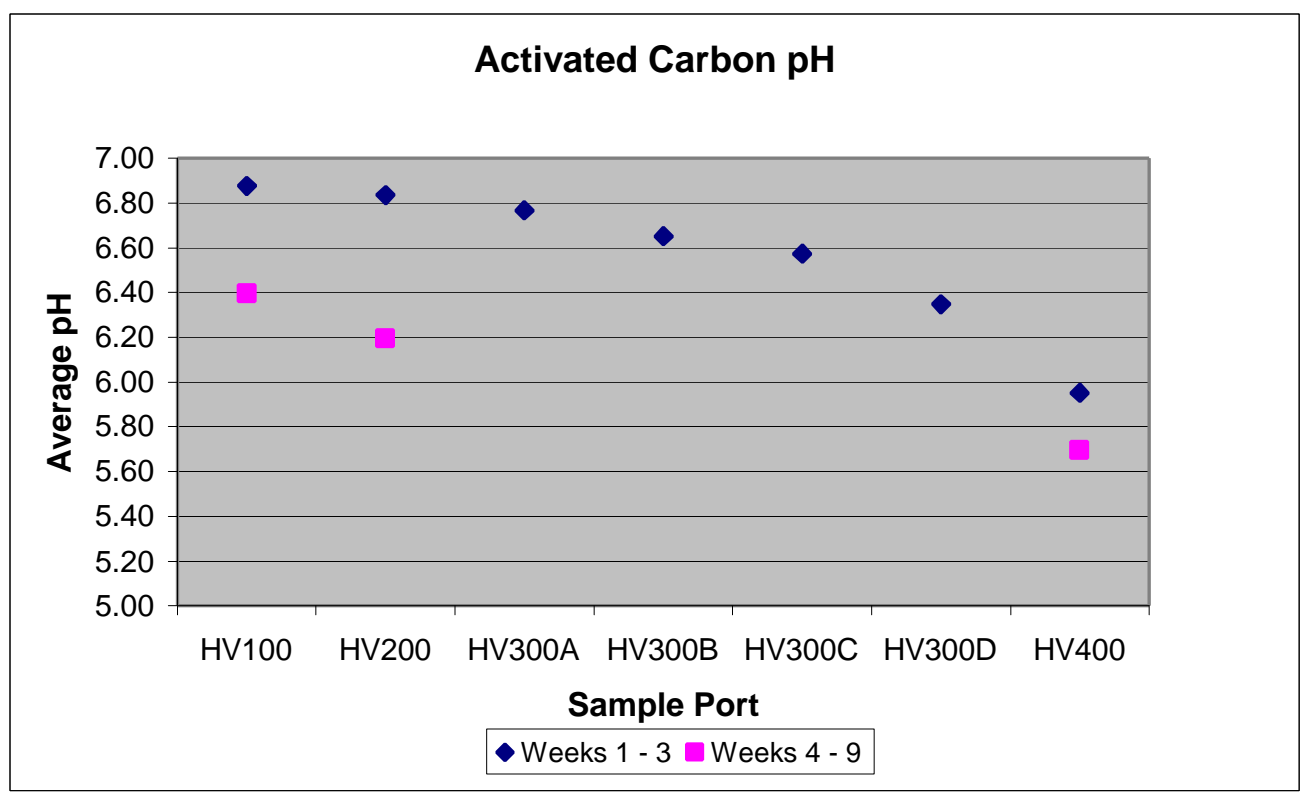

Fig. 7. Average pH results from GAC pilot system.

\subsubsection{Flexibility}

Two parallel trains of 150 gpm each allow for greater on-stream time for the system. One train can be offline for maintenance while the second is treating spring water. The columns will be piped to allow flexibility to operate any column in the lead, middle, or lag position. Additionally during high flow conditions, two columns in a train may be operated if necessary while the third is offline for backwash or change out.

\subsubsection{Secondary Wastes}

An activated carbon based treatment system will generate greater quantities of secondary waste than the ozone/UV system. These secondary waste streams include used filters, spent carbon, and the backwash water. Filter change out is assumed to be performed two times per month, resulting in an annual waste generation rate of $19 \mathrm{ft}^{3} /$ year. Carbon change out is assumed to be performed one time per year for each train ( 2 columns/year) resulting in an annual waste generation rate of 20,000 lb/year. The actual change out rate will be based on utilization by monitoring mercury levels between each column and the discharge. It is anticipated that the spent carbon will meet the waste acceptance criteria for Environmental Management Waste Management Facility disposal cell.

Backwash water is generated from column change out and bed maintenance (if required). When a carbon bed is changed out, the column is backwashed to remove fines prior to placing it into operation. This operation is expected to generate approximately 24,000 gal per event. Assuming one carbon change out per train per year, a total of 48,000 gal of water will be generated. To minimize the cost of operating the system, treated spring water will be used for backwashing the system. A collection tank would be provided at the back end of the system to provide a source of treated water for backwashing. It is anticipated that the volume of water generated by backwash operations can easily be accommodated as makeup water at the Y-12 Complex's Central Pollution Control Facility. 


\subsubsection{System Sensitivity}

Operational experience at CMTS has indicated that chlorine in the water to be treated has a detrimental effect on the mercury removal efficiency. In August 2001, the CMTS experienced a mercury exceedance on its National Pollutant Discharge Elimination System discharge limits. The most probable cause of this exceedance was potable (chlorinated) water entering the catch basin supplying the CMTS. It is believed that the chlorine in the water preferentially bounded to the adsorption sites in the carbon, allowing a portion of the mercury in the water to exit the filters untreated. As a result, sources of chlorinated water will need to be minimized to prevent it from entering the carbon columns. One method for accomplishing this is to collect and utilize groundwater treated at the facility for backwashing the columns.

\subsubsection{Health and Safety}

Health and safety concerns for GAC come from exposure to the caustic used for $\mathrm{pH}$ adjustment. This hazard can be controlled through the use of diking and personal protective equipment for spill control such as gloves, face shield, and aprons should be worn during handling of the materials. Activated carbon is a known oxygen scavenger, as such entry to the columns for inspection during carbon changeout will require special precautions. These precautions are adequately addressed in current Y-12 Complex Confined Space Entry procedures.

\subsection{OZONE/UV}

\subsubsection{Technology Development}

Ozone/UV is primarily used for disinfection, destruction of organic compounds, and odor control in wastewater treatment systems. The use of this technology in large-scale mercury removal is still unproven. The pilot scale unit was operated at $200 \mathrm{~mL} / \mathrm{min}$ and still has a number of variables that are untested or unknown. A number of technical issues including scale up to $4 \mathrm{~L} / \mathrm{min}$ or more, reactor temperature, ozone dosing requirements, transfer efficiencies, and reaction times should be resolved before the technology is deployed as a full-scale system.

During the laboratory studies, higher mercury removal efficiencies were observed when the ozone was introduced directly into the UV reactor. In this configuration the ozone would be converted to $\mathrm{OH}^{\bullet}$ radicals as it crosses the gas/liquid interface. As a result, the gas/liquid transfer was the limiting step. The combined reactor configuration was not modeled in the field studies. Construction of a duel ozone/UV reactor may result in the higher mercury removal efficiencies previously observed. A commercially available method to a combined reactor may be achieved using a venturi to mix the gas/liquid streams. A venturi system would increase the liquid/gas phase transfer efficiency and potentially reduce the total amount of ozone/UV residence time required to operate the treatment system.

The effects of water temperature on the operation of the system were not fully explored. The water jacket around the ozone-water reactor would need to be duplicated in a full-scale system. Elimination of the water jacket may affect several system parameters such as increasing the amount of ozone entering the spring water due to lower water temperature. The rate for the ozone mercury oxidation reaction may change, and the lower water temperature spring water would 
affect the performance of the air stripper by reducing the Henry's Law constant for mercury. The effects of temperature discrepancies from the lab scale and continuous flow to a full-scale system are not fully addressed.

\subsubsection{Treatment Equipment}

The current Y-12 Complex ozone system at the 9409-2 cooling towers uses compressed air from the plant air system to feed the ozone generators. This air is cleaned and dried by the plant and requires little additional pretreatment prior to entering the ozone system. The cooling tower ozone system includes molecular sieve beds to strip out the nitrogen from the air and feed a gas stream containing $88 \%$ to $90 \%$ oxygen to the generator. This system has been operating with routine maintenance for approximately 10 years.

During the sizing of the ozone generator, the manufacturer recommends running each generator at $50 \%$ of its rated capacity. The generators are more reliable and will not burn out the dielectric tubes as quickly. The systems should not be run above $85 \%$ of their rated capacity.

\subsubsection{Support Equipment}

Ozone is generated by passing oxygen across a charged dielectric tube. To maximize the life of the dielectric tube, a gas preparation system is required to insure a clean dry feed. The gas preparation system normally consists of a compressor or source of compressed air; filtering and drying equipment to remove oil, dust, and water from the feed; and refrigeration or heat exchangers to cool the air and condense excess water before it is dried. Drying is accomplished by passing the gas through a heat reactivated desiccant (silica gel, alumina gel, or calcium chloride) dryer with purge. To maximize the amount of ozone produced by a generator, commercial air feed units may include an oxygen concentrator. The concentrator is composed of two molecular sieve beds to separate the nitrogen from the air stream, resulting in a feed to the generator containing $88 \%$ to $90 \%$ oxygen. The feed treatment system will require cooling water to operate properly. According to the vendor information, approximately $6 \mathrm{gpm}$ of cooling water will be required for a pretreatment skid feeding a 150-gpm ozone/UV system, or a total of $12 \mathrm{gpm}$ cooling water would be required for the 300 -gpm two train system.

Based on the operation of the field unit, it is anticipated that the ozone would be introduced into the spring water through a sparge tank in the treatment system. The sparge tank provides the gas/liquid phase mass transfer for the ozone as well as the required 5-minute residence time. Samples collected from filtered water and at the discharge of the ozone reactor indicate that there is no significant mercury loss due to volatilization during this sparging step. Ozone, however, would be lost in the vapor space above the reactor. To address this excess ozone, a destruction module would need to be installed in the off-gas.

\subsubsection{Flexibility}

Two parallel trains of 150 gpm each allow for greater on-stream time for the system. One train can be offline for maintenance while the second is treating spring water.

\subsubsection{Secondary Wastes}

Secondary wastes include personal protective equipment, used filters, and spent vapor phase carbon used to capture mercury from the off-gas of the air stripper. Filter change out is assumed to be performed two times per month, resulting in an annual waste generation rate of $13 \mathrm{ft}^{3} /$ year. 
The spent carbon will be significantly less than that generated from the GAC based treatment system. Carbon change out assumed to be performed once every 5 years resulting in an annual rate of $2000 \mathrm{lb} /$ year. The actual change out rate will be based on utilization by monitoring mercury levels at the discharge. It is anticipated that the spent carbon will meet the waste acceptance criteria for Environmental Management Waste Management Facility disposal cell.

\subsubsection{System Sensitivity}

One of the operational concerns with the use of ozone is the capability to shut down and restart the generator rapidly. The manufacturers of ozone systems have indicated that the generator can be quickly restarted as long as the dielectric tubes are maintained dry. Experience indicates that if the discharge line from the generator is closed off and back pressure is maintained on the system, moisture will not have an opportunity to get to the dielectric tubes allowing for a fast restart once gas flow is restored through the unit.

\subsubsection{Health and Safety}

Stannous chloride is an irritant to the respiratory tract and will require the use of an approved dust respirator while handling solid/powder form. In addition, general purpose gloves, safety glasses/goggles, and lab coats are also recommended. As stannous chloride is a reducing agent, it should not be stored in an area that has the potential for ozone to be present in the air. Ozone has an exposure limit of $0.1 \mathrm{ppm}$ in the air. As a result, ambient monitors will be necessary to warn of leaks in the system and shut down generators to prevent exposure to personnel.

\section{COST EVALUATION}

This section provides the relative costs for 300 gpm water treatment systems based on activated carbon and ozone/UV mercury removal technologies. Both systems are assumed to be sited near the current 9999-4 building location. As a result, the demolition costs for either facility are assumed to be the same and are not included in the estimate. In addition, the cost of the water collection system is independent of the water treatment technology so it is also not included in the estimate. The estimate includes the initial capital cost for each facility as well as the anticipated operation and maintenance (O\&M) costs assuming a 25-year life.

\subsection{GRANULAR ACTIVATED CARBON}

The total life cycle cost for the 300-gpm GAC based water treatment system is approximately $\$ 5.4 \mathrm{M}$. Capital costs for this system are $\$ 1.7 \mathrm{M}$ and include six 8 -ft diameter by 10 -ft high carbon columns consisting of two parallel trains of three. Support equipment includes pre- and post-filters, one each backwash holding and feed tank, and $\mathrm{pH}$ adjustment system. The control system is relatively simple and consists of flow monitors and controllers to maintain a constant 150-gpm flow rate through the columns adjusting for varying pressure drop across the filters. In addition a new pre-engineered structure approximately $2400 \mathrm{ft}^{2}$ is included to house the carbon columns and support systems. The structure will include lighting and ventilation necessary for intermittent operational attention. 
The O\&M costs for the system are approximately $\$ 3.7 \mathrm{M}$. This cost is based on an annual operating cost of approximately $\$ 227 \mathrm{~K}$ escalated at a rate of $3.7 \%$ over 25 years. Annual operating costs include one column change out per year per treatment train and include unloading, loading, and backwashing the column. Additional O\&M costs include filter change outs as well as makeup of the $\mathrm{pH}$ adjustment chemicals. Other costs included are the maintenance of the chemical feed pumps and agitators on the backwash feed and hold tanks.

\subsection{OZONE/UV}

The total life cycle cost for the 300-gpm ozone/UV based water treatment system is approximately $\$ 5.5 \mathrm{M}$. Capital costs for this system is $\$ 1.5 \mathrm{M}$ and includes two trains containing a total of four ozone generators, two sets of ozone and UV reactors, and air strippers. Support equipment includes pre-filters, ozone destruction units, vapor phase mercury collection units, compressors, and feed gas preparation systems. The control system is relatively simple and consists of flow monitors and controllers to maintain a constant 150-gpm flow rate through the columns adjusting for varying pressure drop across the filters. The control system will also initiate the ozone generators when flow through the system is sensed. In addition a new preengineered structure approximately $1000 \mathrm{ft}^{2}$ is included to house the carbon columns and support systems. The structure will include lighting and ventilation necessary for intermittent operational attention.

The O\&M costs for the system are approximately $\$ 4.0 \mathrm{M}$. This cost is based on an annual operating cost of approximately $\$ 249 \mathrm{~K}$ escalated at a rate of $3.7 \%$ over 25 years. Annual operating costs include change outs of the UV lamps and annualized cost of changing out ozone generation tubes once every 3 years. Additional O\&M costs include filter change outs as well as upkeep of the air stripper blowers and trays and the vapor phase mercury removal system.

\section{CONCLUSIONS AND RECOMMENDATIONS}

The purpose of this document is to evaluate the results of the pre-design study for the selection of a mercury removal technology for the Big Spring Water Treatment System. A summary of the factors considered is provided in Table 2 .

\subsection{CONCLUSIONS}

In general, the following conclusions can be made:

- Both treatment technologies have demonstrated the capability to remove mercury from the Outfall 51 spring water to levels below $200 \mathrm{ng} / \mathrm{L}$.

- Results from the pre-design study indicate activated carbon has a lower effluent concentration than ozone/UV. 
Table 2. Technology comparison

\begin{tabular}{|c|c|c|c|}
\hline Category & Factor & GAC & Ozo \\
\hline \multirow[t]{2}{*}{ Mercury Removal } & $200 \mathrm{ppt}$ limit & - Demonstrated & - Demonstrated at field sc \\
\hline & 51 ppt goal & $\begin{array}{l}\text { - Approaches goal (except for initial peak associated } \\
\text { with flushing carbon fines) }\end{array}$ & - Needs additional field sc \\
\hline \multirow[t]{6}{*}{ Operability } & $\begin{array}{l}\text { Technology } \\
\text { Development }\end{array}$ & $\begin{array}{l}\text { - Standard wastewater treatment technology } \\
\text { - Proven for mercury treatment at Y-12 Complex } \\
\text { - } \text { Efficient and simple to operate }\end{array}$ & $\begin{array}{l}\text { - Standard wastewater tre } \\
\text { - Unproven for mercury t } \\
\text { - Immature technology fo. }\end{array}$ \\
\hline & $\begin{array}{l}\text { Treatment } \\
\text { Equipment }\end{array}$ & - Standard equipment design & $\begin{array}{l}\text { - Standard equipment des } \\
\text { - Use of compressed air fi } \\
\text { air system proven } \\
\text { - Ozone generator must b }\end{array}$ \\
\hline & $\begin{array}{l}\text { Support } \\
\text { Equipment }\end{array}$ & $\begin{array}{l}\text { - Pre-filtration required to filter silt } \\
\text { - } \text { Post-filtration required to remove carbon fines } \\
\text { - } \text { pH adjustment required for discharge }\end{array}$ & $\begin{array}{ll}\text { - Gas preparation system } \\
\text { feed consisting of: } \\
\text { - } \quad \text { Compressor or souı } \\
\text { - } \quad \text { Filtering and drying } \\
\text { dust, and water } \\
\text { - } \quad \text { Refrigeration or hec } \\
\text { condense water } \\
\text { - Oxygen concentratc } \\
\text { - Cooling water } \\
\text { - Ozone destruction modu }\end{array}$ \\
\hline & Flexibility & $\begin{array}{l}\text { Two parallel trains of } 150 \text { gpm allow for greater on- } \\
\text { stream time for the system. } \\
\text { - Piping manifold configuration allows for any column } \\
\text { to be in any position. } \\
\text { - Each train can be operated with only two columns, if } \\
\text { necessary. }\end{array}$ & $\begin{array}{l}\text { - Two parallel trains of } 1: \\
\text { stream time for the syst } \epsilon\end{array}$ \\
\hline & Secondary Wastes & $\begin{array}{l}\text { - } 20,000 \mathrm{lb} / \text { year spent liquid phase carbon } \\
\text { - } 48,000 \mathrm{gal} / \text { year backwash water } \\
\text { - } 19 \mathrm{ft}^{3} / \text { year spent filters }\end{array}$ & $\begin{array}{l}\text { - } 2000 \mathrm{lb} / \text { year spent vapo } \\
\text { (need additional field sti } \\
\text { usage) } \\
\text { - } 13 \mathrm{ft}^{3} / \text { year spent filters }\end{array}$ \\
\hline & $\begin{array}{l}\text { System } \\
\text { Sensitivity }\end{array}$ & $\begin{array}{l}\text { Chlorinated water causes system upsets (use treated } \\
\text { water to backwash the system) }\end{array}$ & $\begin{array}{l}\text { - Dielectric tube used to c } \\
\text { must be kept dry (maint: } \\
\text { excluding moisture from }\end{array}$ \\
\hline
\end{tabular}


Table 2 (continued)

\begin{tabular}{|c|c|c|c|}
\hline \multirow{2}{*}{$\begin{array}{c}\text { Category } \\
\text { Operability (cont.) }\end{array}$} & Factor & GAC & $\overline{\mathrm{Ozo}}$ \\
\hline & Health \& Safety & $\begin{array}{l}\text { - Caustic chemicals used for } \mathrm{pH} \text { adjustment } \\
\text { - Carbon is an oxygen scavenger, which will create an } \\
\text { oxygen deficient atmosphere within the columns. }\end{array}$ & $\begin{array}{l}\text { - Stannous chloride powd } \\
\text { - The interaction of a stro } \\
\text { strong reducer (stannous } \\
\text { uncontrolled chemical rt } \\
\text { - Ambient air monitors fo }\end{array}$ \\
\hline \multirow[t]{3}{*}{ Cost } & Total & - $\$ 5.4 \mathrm{M}$ & $\cdot \$ 5.5 \mathrm{M}$ \\
\hline & Capital & - $\$ 1.7 \mathrm{M}$ & - $\$ 1.5 \mathrm{M}$ \\
\hline & O\&M & - $\$ 3.7 \mathrm{M}$ & - $\$ 4.0 \mathrm{M}$ \\
\hline
\end{tabular}


- Activated carbon is a conventional treatment technology that has a proven track record of treatment efficiency, operability, and reliability. Based on the pilot studies, the highest discharge levels were observed immediately after the columns were charged with fresh carbon. During the Phase II study, these levels never exceeded the $200 \mathrm{ng} / \mathrm{L}$ discharge limit established in the ROD and are expected to only occur during carbon change out. These elevated discharge levels are presumed to be a result of carbon fines not flushed during the initial backwash exiting the columns. During the pilot study a 5-micron filter was used in the discharge line. In the full-scale treatment design, a more efficient 1-micron filter will be provided to reduce the impact of the fines on the mercury discharge levels. The pilot study also showed that after the fines are flushed from the system, the carbon system was able to consistently meet mercury discharge levels under $60 \mathrm{ng} / \mathrm{L}$.

- Ozone/UV for treating mercury has a lack of technical maturity. A number of technical issues including scale-up to $4 \mathrm{~L} / \mathrm{min}$ or more, reactor temperature, ozone dosing requirements, transfer efficiencies, and reaction times should be resolved before the technology is deployed as a full-scale system. The resolution of these issues should optimize the overall mercury removal efficiency and reduce the life cycle cost. The levels at which mercury has been removed from Outfall 51 water in these studies may justify provisions for continuing resources to develop the technology.

- The ozone/UV technology has considerable potential for mercury removal without generating significant quantities of secondary waste. In addition, the physical size of an ozone/UV treatment system would compare favorably to activated carbon.

\subsection{RECOMMENDATIONS}

Based on information currently available, it is recommended that the full-scale water treatment system be designed and constructed using GAC as the mercury removal technology. In an attempt to obtain mercury discharge levels below $51 \mathrm{ng} / \mathrm{L}$, it is recommended that an extra column be added to the two-column configuration used in the pilot study. The treatment system would consist of two parallel 150 gpm trains of three columns in series for a maximum 300-gpm flow rate as required in the ROD.

Furthermore, the ozone/UV system has demonstrated its ability to obtain mercury discharge levels below $200 \mathrm{ng} / \mathrm{L}$. Although time does not allow the option to develop this technology for use on this project, it is recommended that further study be performed to resolve the technical issues associated with the ozone/UV system due to the potential for future use. 
BJC/OR-1239

\section{RECORD COPY DISTRIBUTION}

File-EMEF DMC-RC 